\title{
"A study on the effect of service quality on customer loyalty and corporate performance in financial industry"
}

\begin{tabular}{|c|c|c|}
\hline \multirow{2}{*}{$\begin{array}{l}\text { AUTHORS } \\
\text { ARTICLE INFO }\end{array}$} & \multicolumn{2}{|l|}{$\begin{array}{l}\text { Chia-Ming Liu } \\
\text { Tsung-Yuan Wang }\end{array}$} \\
\hline & \multicolumn{2}{|c|}{$\begin{array}{l}\text { Chia-Ming Liu and Tsung-Yuan Wang (2017). A study on the effect of service } \\
\text { quality on customer loyalty and corporate performance in financial industry. } \\
\text { Problems and Perspectives in Management, 15(2-2), 355-363. } \\
\text { doi:10.21511/ppm.15(2-2).2017.05 }\end{array}$} \\
\hline DOI & \multicolumn{2}{|c|}{ http://dx.doi.org/10.21511/ppm.15(2-2).2017.05 } \\
\hline RELEASED ON & \multicolumn{2}{|l|}{ Friday, 01 September 2017} \\
\hline RECEIVED ON & \multicolumn{2}{|l|}{ Tuesday, 14 March 2017} \\
\hline ACCEPTED ON & \multicolumn{2}{|l|}{ Monday, 03 July 2017} \\
\hline LICENSE & \multicolumn{2}{|c|}{$\begin{array}{l}\text { This work is licensed under a Creative Commons Attribution-NonCommercial } 4.0 \\
\text { International License }\end{array}$} \\
\hline JOURNAL & \multicolumn{2}{|c|}{ "Problems and Perspectives in Management" } \\
\hline ISSN PRINT & \multicolumn{2}{|l|}{$1727-7051$} \\
\hline ISSN ONLINE & \multicolumn{2}{|l|}{$1810-5467$} \\
\hline PUBLISHER & \multicolumn{2}{|c|}{ LLC "Consulting Publishing Company "Business Perspectives" } \\
\hline FOUNDER & \multicolumn{2}{|c|}{ LLC "Consulting Publishing Company "Business Perspectives" } \\
\hline$\sigma^{0}$ & 6 & ニニこ \\
\hline NUMBER OF REFERENCES & NUMBER OF FIGURES & NUMBER OF TABLES \\
\hline 28 & 1 & 3 \\
\hline
\end{tabular}

(c) The author(s) 2023. This publication is an open access article. 


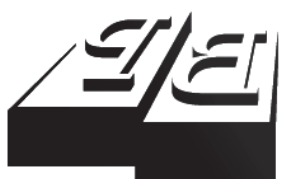

BUSINESS PERSPECTIVES

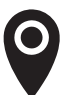

LLC "CPC "Business Perspectives" Hryhorii Skovoroda lane, 10, Sumy, 40022, Ukraine

www.businessperspectives.org

Received on: $14^{\text {th }}$ of March, 2017

Accepted on: $3^{\text {th }}$ of July, 2017

(c) Chia-Ming Liu, Tsung-Yuan Wang, 2017

Chia-Ming Liu, Assistant Professor, Department of International Business, Chang Jung Christian University, Taiwan.

Tsung-Yuan Wang, Assistant Professor, Department of International Business, Chang Jung Christian University, Taiwan, e-mail : wangcy@mail.cjcu.edu.tw

\section{(ㄷ)(1) $(8)$}

This is an Open Access article, distributed under the terms of the Creative Commons Attribution-NonCommercial 4.0 International license, which permits re-use, distribution, and reproduction, provided the materials aren't used for commercial purposes and the original work is properly cited.

\section{A STUDY ON THE EFFECT OF SERVICE QUALITY ON CUSTOMER LOYALTY AND CORPORATE PERFORMANCE IN FINANCIAL INDUSTRY}

\begin{abstract}
Since the government opened to the establishment of new private banks in 1990s, the competition in banking industry has become fierce in Taiwan. Especially, the establishment of financial holding companies after 2000s has resulted in the merge among financial institutions. The competition in banking industry becomes even fiercer. The price war of interest rate among banks gradually shortens the deposit and lending rate difference in banking industry that banks could no longer survive with the traditional business of deposit and lending rate differences. Banks have to attract customers with different service quality, satisfy customer needs, and create new profits for banking industry. Generally speaking, service quality is related to customer satisfaction after receiving service, and satisfaction becomes the internal assessment indicator of financial industry for customers. A lot of excellent foreign businesses or national financial institutions present brilliant competitiveness in the field of finance by the specialty and service quality. Taking Land Bank of Taiwan as the research subject, this study aims to discuss the effect of service quality on customer loyalty and corporate performance in financial industry.

It is discovered in this study that an enterprise enhancing the service quality through the mediation effect of customer loyalty could effectively promote the corporate performance. For this reason, the relationship between customer loyalty and service quality, corporate performance are established in this study, and the results of the analysis could be the reference for banking industry in Taiwan.
\end{abstract}

Keywords service quality, customer loyalty, corporate performance, land bank, financial sector

JEL Classification $\quad$ M31, G21, M21

\section{INTRODUCTION}

Since the government opened to the establishment of new private banks in 1990s, the competition in banking industry has become fierce. Especially, after the establishment of financial holding companies in 2000s, the merge of financial institutions has resulted in fiercer competition in banking industry. Such competition shortens the deposit and lending rate difference in traditional banking industry that banks could no longer survive with the business of deposit and lending rate difference. In this case, banks attract customers with different service quality, satisfy customer needs, and create new profits for banking in dustry. Under the competitive financial environment with meager profits, enhancing the service quality to satisfy customers allows banks to continuously make profit and survive with development. It becomes an essential issue for banking industry. 
A lot of researchers consider service quality as the major competitive tactics and the difference from other banks. From the aspect of service recipients, the enhancement of service quality would promote customer satisfaction and induce customers to receive the next service. The good service quality and the repeated consumption of customers are the source of profits for service businesses. Service businesses would enhance the overall performance when gaining higher profits, and further promote the service quality for the feedback to customers. Such a good cycle would satisfy customers and allow banks to make profits. Service quality, therefore, has become an important indicator of competition in banking industry.

Taking the Land Bank of Taiwan as the research subject, this study aims to discuss the effect of service quality on customer loyalty and corporate performance in financial industry. It intends to understand the correlations between service quality and customer loyalty, between customer loyalty and corporate performance, and between service quality and corporate performance for the reference of Land Bank of Taiwan.

\section{LITERATURE REVIEW}

\subsection{Service quality, customer loyalty, and corporate performance}

Generally speaking, service quality is an abstract idea, the cognition difference of service judged by consumers' subjective differences, i.e., the comparison between the pre-expected service of cusomers and the actual perception after receiving service. It is also the subjective judgment of affairs rather than the quantatitive measurement of the property or characteristics of affairs. Regarding the management, higher correctness and rapidness of service is required in banking industry. Colletti pointed out service quality as the degree of service offered by a bank satisfying customers' needs and expectations (Colletti, 1987). Soteriou and Frei also considered service quality as the variance of operation quality and operation process and the key factor in service quality performance and customer satisfaction (Soteriou, 1999; Frei, 1999).

Ten dimensions to measure service quality developed by Parasuraman, Zeithaml, and Berry (1985) aiming at customers in banking industry, credit card companies, securities industry, and product maintenance companies are the most broadly applied for measuring service quality. Based on above 10 dimensions, Parasuraman, Zeithaml and Berry (1988) further investigated banking industry, long distance call companies, securities brokers, credit card centers, and appliance maintenance industry and reduced 5 dimensions to cover
22 questions. The revised scale contained tangibles, reliability, empathy, responsiveness, and assurance. Accordingly, 5 quality dimensions proposed by them are utilized in this study for measuring quality of service of the bank, as well as to draw the factors in the measurement of service quality.

Under the fiercely competitive financial market, enterprises extremely emphasize and concern about the effective enhancement of consumers' repurchase intention and create consumer loyalty to products. Jacoby and Chestnut (1978) proposed that customer loyalty was the permanent existence and was the psychological decision and assessment after a decision-making unit considering one or more brands as well as the brand commitment. Hennig and Hansen (2000) pointed customer loyalty as customers' positive attitude toward service or product providers. Kotler (2011) considered that an enterprise had to cultivate long-term relationship with customers so as to enhance customers' repurchase intention.

Regarding the measurement of customer loyalty, Fornell (1992) measured loyalty with customers' repurchase intention and tolerance for price. Jones and Sasser (1995) measured customer loyalty with (1) repurchase intention, to ask customers about the product or service repurchase intention in the future, (2) primary behavior, referring to customers' actual repurchase behaviors, and (3) secondary behavior, including customer behaviors of introducing customers, word of mouth, or recommendation. Bhote (1996) used customers' retention ratio, turnover rate, the number and persistence of core customers, and core value of customers as the 
measurement indicators. Furthermore, customer loyalty could be measured with popularization and profundity. The former referred to the brand and quality of product or service and the product or service providers and enterprises. The latter, on the other hand, referred to the strong intention of repeated purchase.

Referring to previous research concepts, it is considered in this study that the measurement of customer loyalty should cover the measurement of behavior and attitude. Repurchase and recommendation proposed by Jones and Sasser (1995) are, therefore, used in this study as the indicators and the questions to measure customer loyalty.

Most researchers agreed that "performance was the measurement of organizational goal reaching certain degree" (Robbins, 1990). Apparently, performance was a primary indicator for enterprises. Although a lot of researchers proposed similar opinions and definitions of performance, the measurement standards of performance were different. Venkatraman and Amanujam (1986) proposed to measure corporate performance with financial performance, business performance, and organizational performance. Delaney and Husleid (1996) applied organizational performance and market performance to measure performance, where organizational performance contained quality of product/service, development of new product/service, ability to attract talents, ability to retain talents, customer satisfaction, relationship between managers and employees, and relationship among employees, and market performance included market capability, revenue growth rate, profitability, and market share.

In this study, the measurement of corporate performance is divided into productivity, profitability, and growth capacity, and the questions are properly revised to become the converted "corporate performance" scale.

\subsection{Relationship among dimensions}

(1) Correlations between service quality and customer loyalty. Parasuraman et al. (1988) proved the positive correlation between service quality and customer loyalty, but the negative correlation with transfer behavior and external response. Moreover, research also indicated that the effect of service quality on post-purchase behavior would change with the service property of enterprises. Rust et al. (1995) mentioned that service quality would affect customer loyalty; customers would present satisfactory post-purchase behavior when perceiving higher service quality to further enhance the customer loyalty and repurchase intention, i.e., positive correlations between service quality and customer loyalty. However, dissatisfactory postpurchase behavior (e.g., negative word of mouth and public complaint) appears to have negative correlations with customer satisfaction.

Dong and Cannon (1997), as well as Garbarino and Johnson (1999) include service quality as one of the most frequently analyzed customer loyalty determinants. Especially, service quality is very important for customer satisfaction, and it will impact customer loyalty (Cronin \& Taylor, 1992; Oliver, 1999).

(2) Correlations between customer loyalty and corporate performance. The establishment of customer loyalty to enterprises has been a goal for marketing staff. Having customers preliminarily know about an enterprise with favorable information to further present good impression could result in certain customer loyalty. Having customers actively seek for service so that an enterprise has more opportunities to establish the mutual trust could promote customer loyalty and create profits for the enterprise. Loyal customers are the key factor in enterprises making profits, and market performance could affect customer loyalty.

Heskett et al. (1994) suggest the service-profit chain, which includes the relationships between customer loyalty, satisfaction, profitability, and productivity. There are many empirical studies which link performance, customer loyalty, and satisfaction (Chi, Christina G., \& Dogan Gursoy, 2008; Bernhardt et al., 2000). For this reason, they are critical issues for banks enhancing the service quality, establishing good market performance to promote customer loyalty, and increasing corporate performance.

(3) Correlations between service quality and corporate performance. Rust et al. (1995) tested the relationship between quality and financial re- 
turns with return on quality. They mentioned that the returns on the expense of service quality were decreasing; when the improvement of service quality exceeded certain point, the expense of service quality did not appear the cost benefit. Accordingly, the improvement of service quality stresses on increasing income, rather than reducing costs as the expense purpose.

Heskett et al. (1994) and Loveman (1998) also indicated that satisfactory employees could provide better service to enhance customers' perceived service quality. Customers would enhance the satisfaction after receiving high-quality service, and customer loyalty was then promoted to enhance the profits of the company.

Levesque and Mc. Dougall (1996), Newman (2001) and Caruana (2002) all found that service quality and satisfaction have close relationship with customer loyalty through repurchase intentions. It seems service quality to customers is a important key for success in today's competitive banking industry. Hussein and Jabnoun (2006) revealed that financial institutions could improve the service quality to enhance the profitability, and a bank with high profits had more resources to improve the service quality and promote the profits.

According to the literature mentioned above, the following hypotheses are proposed in this study:

H1: Service quality presents positive effects on repurchase intention in customer loyalty.

H2: Service quality shows positive effects on primary behavior in customer loyalty.
H3: Service quality reveals positive effects on secondary behavior in customer loyalty.

H4: Customer loyalty appears positive effects on profitability in corporate performance.

H5: Customer loyalty presents positive effects on productivity in corporate performance.

H6: Customer loyalty shows positive effects on growth capacity in corporate performance.

H7: Service quality reveals positive effects on profitability in corporate performance.

H8: Service quality appears positive effects on productivity in corporate performance.

H9: Service quality presents positive effects on growth capacity in corporate performance.

\section{RESEARCH METHODOLOGY}

\subsection{Research framework}

This study aims to discuss the relations among service quality, customer loyalty, and corporate performance. The diagram of various hypotheses is shown below.

\subsection{Measurement of research variable}

\subsubsection{Service quality}

Referring to Parasuraman, Zeitithaml, and Berry (1988), service quality is classified into tangibles, reliability, responsiveness, assurance, and empathy.

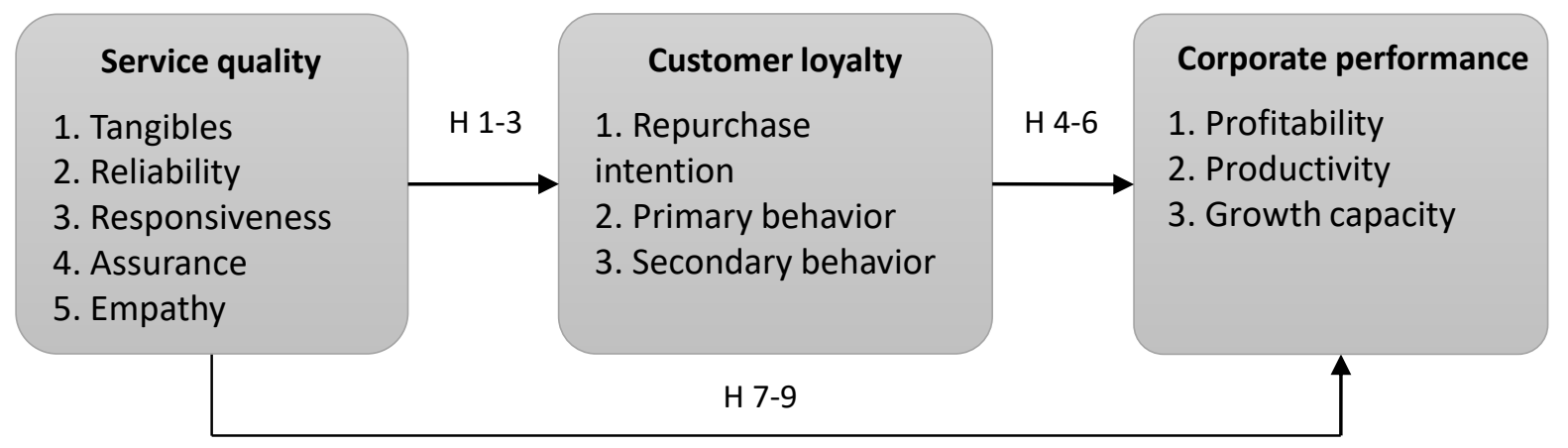

Figure 1. Research framework 


\subsubsection{Customer loyalty}

Referring to Jones and Sasser (1995), it is divided into repurchase intention, primary behavior, and secondary behavior.

\subsubsection{Corporate performance}

Based on the literature mentioned above, it contains productivity, profitability, and productivity.

\subsection{Research sample and sampling data analysis}

The questionnaires are distributed and collected on site. Customers of the branches of Land Bank of Taiwan in Tainan areas are sampled for the survey. Total 300 copies of questionnaire were distributed and 272 copies were collected, including 250 valid copies. The valid retrieval rate is $83.3 \%$. The retrieved questionnaires were analyzed with SPSS, and Factor Analysis, Reliability Analysis, and Regression Analysis were utilized for testing hypotheses.

\section{RESULT AND ANALYSIS}

Multiple Regression Analysis of service quality and customer loyalty

\subsection{Factor Analysis}

The service quality scale in this study indudes 5 factors, namely "tangibles", "reliability", "responsiveness", "assurance", and "empathy", with Factor Analysis. Three factors, "repurchase intention", "primary behavior", and "secondary behavior", are extracted for the customer loyalty scale, and "profitability", "productivity", and "growth capacity" are extracted for the corporate performance scale.

\subsection{Regression Analysis of service quality and customer loyalty}

\subsubsection{Regression Analysis of service quality and repurchase intention:}

$R^{2}$ appears 0.445 revealing the service quality could explain $44.5 \%$ variance of repurchase intention $R^{2}=0.434$. The overall service quality achieves the significance $F=39.179, p<0.001$, where "tangibles", "reliability", and "empathy" show remarkably positive effects on repurchase intention in customer loyalty

$\beta=0.174, p<0.01 ; \beta=0.283, p<0.001$;

$\beta=0.442, p<0.001$.

$\mathrm{H} 1$ is, therefore, supported.

Table 1. Multiple Regression Analysis of service quality and customer loyalty

\begin{tabular}{|c|c|c|c|}
\hline Dependent variable $\rightarrow$ & & Customer loyalty & \\
\hline Independent variable $\downarrow$ & Repurchase intention & Primary behavior & Secondary behavior \\
\hline \multicolumn{4}{|l|}{ Service quality } \\
\hline Tangibles & $.174^{* *}$ & $.154^{*}$ & .127 \\
\hline Reliability & $.283^{* * *}$ & $.257^{* *}$ & .141 \\
\hline Responsiveness & -.102 & .061 & .147 \\
\hline Assurance & .095 & .077 & .102 \\
\hline Empathy & $.442^{* * *}$ & $.206^{* *}$ & $.238^{* * *}$ \\
\hline$F$ value & 39.179 & 22.027 & 21.431 \\
\hline$R^{2}$ & .445 & .311 & .305 \\
\hline $\bar{R}^{2}$ & .434 & .297 & .291 \\
\hline
\end{tabular}

Note: ${ }^{\star} \mathrm{P}<0.05^{\star *} \mathrm{P}<0.01^{\star * *} \mathrm{P}<0.001$. 


\subsubsection{Regression Analysis of service quality and primary behavior}

$R^{2}$ appears 0.311 , revealing that service quality could explain $31.1 \%$ variance of primary behavior $\left(\bar{R}^{2}=0.297\right)$. The overall service quality reaches the significance $(F=22.027, p<0.001)$, where "tangibles", "reliability", and "empathy" present notably positive effects on primary behavior in customer loyalty $\beta=0.154, p<0.05 ; \beta=0.257, p<0.01$;

$$
\beta=0.206, p<0.01 \text {. }
$$

\subsubsection{Regression Analysis of service quality and secondary behavior}

$R^{2}$ appears 0.305 , showing that service quality could explain $30.5 \%$ variance of secondary behavior $\left(\bar{R}^{2}=0.291\right)$. The overall service quality achieves the significance $(F=21.431, p<0.001)$, where "empathy" reveals significantly positive effects on secondary behavior in customer loyalty $(\beta=0.238, p<0.001)$. $\mathrm{H} 3$ is, therefore, supported.

In sum, according to the data given above, tangibles, reliability, responsiveness, assurance, and empathy in service quality would directly affect repurchase intention, primary behavior, and secondary behavior in customer loyalty in financial industry. Customer loyalty in financial industry, therefore, could be promoted by the enhancement of service quality.

\subsection{Multiple Regression Analysis of customer loyalty and corporate performance}

\subsubsection{Regression Analysis of customer loyalty and profitability}

$R^{2}$ shows 0.587 , presenting that customer loyalty could explain $58.7 \%$ variance of profitability $\left(\vec{R}^{2}=0.582\right)$. The overall customer loyalty reaches the significance $(F=116.519, p<0.001)$, where "repurchase intention", "primary behavior", and "secondary behavior" reveal remarkably positiveeffectson profitabilityin corporateperformance $\beta=0.326, p<0.001 ; \beta=0.216, p<0.01$;

$\beta=0.330, p<0.001$.

$\mathrm{H} 4$ is, therefore, supported.

\subsubsection{Regression Analysis of customer loyalty and productivity}

$R^{2}$ reveals 0.316 , showing that customer loyalty could explain $31.6 \%$ variance of productivity $\bar{R}^{2}=0.308$. The overall customer loyalty reaches the significance $(F=37.928, p<0.001)$, where "repurchase intention" and "primary behavior" appear notably positive effects on productivity in corporate performance $(\beta=0.239, p<0.01 ; \beta=0.294, p<0.001)$.

$\mathrm{H} 5$ is, therefore, supported.

\subsubsection{Regression Analysis of customer loyalty and growth capacity}

$R^{2}$ appears 0.195, showing that customer loyalty could explain $19.5 \%$ variance of growth capacity $R^{2}=0.185$. The overall customer loyalty achieves the significance $(F=19.865, p<0.001)$, where secondary behavior presents notably positive effects on growth capacity in corporate performance $(\beta=0.287, p<0.01)$. H6 is, therefore, supported.

According to the data given above, corporate performance in financial industry is affected by repurchase intention, primary behavior, and secondary behavior in customer loyalty, where profitability, productivity, and growth capacity appear to have direct effects, revealing that corporate performance would be changed by the effect of customer loyalty. In this case, businesses should enhance the customer loyalty as much as possible to effectively promote the corporate performance.

\subsection{Multiple Regression Analysis of service quality and corporate performance}

\subsubsection{Regression Analysis of service quality and profitability}

$R^{2}$ shows 0.323 , revealing that service quality could explain $32.3 \%$ variance of profitability $R^{2}=0.309$. The overall service quality reaches the significance $(F=23.292, p<0.001)$, 
Table 2. Multiple Regression Analysis of customer loyalty and corporate performance

Data source: self-organized in this study.

\begin{tabular}{|c|c|c|c|}
\hline Dependent variable $\rightarrow$ & \multicolumn{3}{|c|}{ Corporate performance } \\
\hline Independent variable $\downarrow$ & Profitability & Productivity & Growth capacity \\
\hline \multicolumn{4}{|l|}{ Customer loyalty } \\
\hline Repurchase intention & $.326^{* * *}$ & $.239 * *$ & .145 \\
\hline Primary behavior & $.216^{* *}$ & $.294^{* * *}$ & .061 \\
\hline Secondary behavior & $.330^{* * *}$ & .101 & $.287 * *$ \\
\hline F value & 116.519 & 37.928 & 19.865 \\
\hline$R^{2}$ & .587 & .316 & .195 \\
\hline $\bar{R}^{2}$ & .582 & .308 & .185 \\
\hline
\end{tabular}

Note: ${ }^{\star} \mathrm{P}<0.05^{\star \star} \mathrm{P}<0.01{ }^{* * *} \mathrm{P}<0.001$.

where "reliability", "assurance", and "empathy" $\beta=0.185, p<0.05 ; \beta=0.185, p<0.05$; present significantly positive effects on profitabil- $\beta=0.159, p<0.05$. ity in corporate performance

$$
\begin{aligned}
& \beta=0.235, p<0.01 ; \beta=0.172, p<0.05 \\
& \beta=0.269, p<0.001
\end{aligned}
$$

$\mathrm{H} 8$ is, therefore, supported.

$\mathrm{H} 7$, is therefore, supported.

\subsubsection{Regression Analysis of service quality and productivity}

$R^{2}$ appears 0.184 , presenting that service quality could explain $18.4 \%$ variance of productivity $\vec{R}^{2}=0.167$. The overall service quality reaches the significance $(F=10.984, p<0.001)$, where "tangibles", "responsiveness", and "empathy" show remarkably positive effects on productivity in corporate performance

\subsubsection{Regression Analysis of service quality and growth capacity}

$R^{2}$ reveals 0.200 , showing that service quality could explain $20.0 \%$ variance of growth capacity $\bar{R}^{2}=0.183$. The overall service quality achieves the significance $(F=12.172, p<0.001)$, where "tangibles", "responsiveness", and "empathy" appear notably positive effects on growth capacity in corporate performance

$\beta=0.150, p<0.05 ; \beta=0.210, p<0.05$;

$\beta=0.291, p<0.001$.

H9 is, therefore, supported.

Table 3. Multiple Regression Analysis of service quality and corporate performance

\begin{tabular}{|c|c|c|c|}
\hline Dependent variable $\rightarrow$ & \multicolumn{3}{|c|}{ Corporate performance } \\
\hline Independent variable $\downarrow$ & Profitability & Productivity & Growth capacity \\
\hline \multicolumn{4}{|l|}{ Service quality } \\
\hline Tangibles & .122 & $.185^{*}$ & $.150^{*}$ \\
\hline Reliability & $.235^{* *}$ & -.006 & -.111 \\
\hline Responsiveness & -.023 & $.185^{*}$ & $.210^{*}$ \\
\hline Assurance & $.172^{*}$ & .054 & .033 \\
\hline Empathy & $.269^{* * *}$ & $.159 *$ & $.291^{* * *}$ \\
\hline F value & 23.292 & 10.984 & 12.172 \\
\hline$R^{2}$ & .323 & .184 & .200 \\
\hline $\bar{R}^{2}$ & .309 & .167 & .183 \\
\hline
\end{tabular}

Data source: self-organized in this study.

Note: ${ }^{\star} \mathrm{P}<0.05^{* *} \mathrm{P}<0.01{ }^{* * *} \mathrm{P}<0.001$. 
According to the data given above, corporate performance in financial industry is affected by tangibles, reliability, responsiveness, assurance, and empathy in service quality, where profitability, productivity, and growth capacity appear to have direct effects, revealing that corporate perfor- mance is changed by the effect of service quality. Businesses, therefore, have to create better service to satisfy customer needs so that the acquired expected experience is more satisfactory. In this case, the corporate performance could be effectively promoted.

\section{CONCLUSION}

From the data given above, the findings are organized as follows.

\section{Effects of service quality on customer loyalty}

With our analysis, the dimensions of tangibles, reliability, responsiveness, assurance, and empathy in service quality could enhance the dimensions of repurchase intention, primary behavior, and secondary behavior in customer loyalty. As a result, it is confirmed that customer loyalty to the product or service provided by the enterprise could be effectively reinforced and promoted after the practice of service quality, and it presents positive correlations.

\section{Effects of customer loyalty on corporate performance}

From the viewpoint of service quality matching with the relationship between loyalty and performance proposed in past literature, a new theoretical framework is constructed in this study. The research findings show the significantly positive effects of service quality on customer loyalty, and customer loyalty presents remarkably positive effects on corporate performance. Such a result proves the hypotheses in this study as well as verifies the correlations between customer loyalty and corporate performance proposed in past research. With the mediation effect of customer loyalty, customer loyalty to enterprises would be enhanced when the perceived service quality is deep that the corporate performance would be promoted.

\section{Relationship among service quality, customer loyalty, and corporate performance}

According to the research findings, the promotion of service quality could effectively enhance corporate performance through the mediation effect of customer loyalty. For this reason, customer loyalty is a mediator between service quality and corporate performance. The finding corresponds to the conclusions of Parasuraman, Zeitithaml and Berry (1988), Hennig and Hansen (2000), and Delaney and Husleid (1996) that the promotion of service quality could enhance corporate performance. Such a conclusion is expected to provide reference for banking industry in Taiwan. In the future, the analysis could be applied to other banks and even different industries to present distinct results.

\section{REFERENCES}

1. Bernhardt, K. L., Donthu, N., Kennett, P. A. (2000). A longitudinal analysis of satisfaction and profitability. Journal of Business Research, 47, 161-171. Retrieved from http://www.sciencedirect.com/science/article/pii/ S0148296398000423

2. Bhote. (1996). The key to Greater Profitability, New York. American Management Association, 31. Retrieved from https://www.
amazon.com/Beyond-CustomerSatisfaction-Loyalty-Profitability/ dp/0814423620

3. Caruana, A. (2002). Service loyalty. The effects of service quality and the mediating role of customer satisfaction. European Journal of Marketing, 36(7/8), 811-828. Retrieved from http:// www.emeraldinsight.com/doi/ abs/10.1108/03090560210430818
4. Chi, Christina, G., \& Dogan, Gursoy. (2008). Employee satisfaction, customer satisfaction, and financial performance: An empirical examination. International Journal of Hospitality Management, available online 31, October 2008. Retrieved from http://www.sciencedirect.com/science/article/pii/ S0278431908000790

5. Colletti, D. L. (1987). Retail Banking Success: A Question of Quality. 
Banking Administration, 63(4), 42-48. Retrieved from https://pdfs. semanticscholar.org/7e96/2c166911 921fef68773de5db75e84cc79aaf.pdf

6. Cronin, J. J., Taylor, S. A. (1992). Measuring service quality: a reexamination and extension. Journal of Marketing, 56(3), 55-68. Retrieved from https://www.jstor. org/stable/1252296?seq=1\#page scan_tab_contents

7. Delaney, J. T., \& Huseid, M. A. (1996). The impact of human resource management practice on perceptions of organizational performance. Academy of Management Journal, 39(4), 949969. Retrieved from https://www. jstor.org/stable/256718

8. Doney, P. M., Cannon, J. P. (1997). An examination of the nature of trust in buyer-seller relationships. Journal of Marketing, 61, 35-51. Retrieved from https://www.jstor. org/stable/1251829?seq=1\#page_ scan_tab_contents

9. Fornell, C. (1992). A National Customer Satisfaction Barometer: The Swedish Experience. Journal of Marketing, 55, 1-22. Retrieved from https://www.jstor.org/ stable/1252129?seq=1\#page_scan_ tab_contents

10. Frei, F. X., Kalakota, R., Leone, A. J., Marx, L. M. (1999). Process variation as a determinant of bank performance: Evidence from the retail banking industry. Management Science 45(9), 1210-1220. Retrieved from https://www.jstor.org/ stable/2634833?seq=1\#page_scan_ tab_contents

11. Garbarino, E., Johnson, M. S. (1999). The different roles of satisfaction, trust and commitment in customer relationships. Journal of Marketing, 63(2), 70-87. Retrieved from https://www.jstor.org/ stable/1251946?seq=1\#page_scan_ tab_contents

12. Hennig, T. T., \& Hansen, U. (2000). Relationship Marketing: Gaining Competitive Advantage through Customer Satisfaction and Customer Retention. Berlin: Springe. Retrieved from https://books.google.com.tw/ books/about/Relationship_Marketing.html?id=xajPg6wdXJEC\&redir esc $=y$
13. Jacoby, J., \& Chestnut, R. (1978). Brand Loyalty: Measurement and Management. NY: John Wiley and Sons. Retrieved from https://books.google.com.tw/ books/about/Brand_Loyalty. html?id=ffkJAQAAMAAJ\&redir esc $=y$

14. Heskett, J. L., Thomas, O. J., Gary, W. L., Sasser, W. E., \& Leonard, A. S. (1994). Putting the Service-Profit Chain to Work. Harvard Business Review, 72(2), 164-174. Retrieved from https://books.google.com.tw/ books/about/Brand_Loyalty. $\mathrm{html}$ ?id=ffkJAQAAMAAJ\&redir_ esc $=y$

15. Hussein, \& Jabnoun N. (2006). Service Quality and Bank Performance: A Comparison of the UAE National and Foreign Banks. Finance India, 20(1), 181. Retrieved from https://www.econbiz.de/ Record/service-quality-bankperformance-a-comparison-of-theuae-national-and-foreign-banks-tamimi-hussein-hassan/10009920701

16. Jones, T. O., \& Sasser, W. E. (1995). Why satisfied customers defect. Harvard Business Review, 73(6), 88-101. Retrieved from https://hbr. org/1995/11/why-satisfied-customers-defect

17. Kotler, P. (2011). Marketing Management: analysis, Planning, Implementation and Control, 13th ed. Englewood Cliffs, NJ: PrenticeHall Inc. Retrieved from https:// www.amazon.com/MarketingManagement-Analysis-PlanningImplementation/dp/B0044L1KPU

18. Levesque, T. J., \& McDougall, G. H. G. (1996). Determinants of customer satisfaction in retail banking. International Journal of Bank Marketing, 14(7), 12-20. Retrieved from https://www.deepdyve.com/lp/ emerald-publishing/determinantsof-customer-satisfaction-in-retailbanking-tWvRHgTsOL

19. Loveman, G. W. (1998). Employee Satisfaction, Customer Loyalty, and Financial Performance-An Empirical Examination of the Service Profit Cfain in Retail Banking. Journal of Service Research, 1(1), 18-31. Retrieved from http://journals.sagepub.com/doi/ abs/10.1177/109467059800100103
20. Newman, K. (2001). Interrogating SERVQUAL: a critical assessment of service quality measurement in a high street retail bank. International Journal of Bank Marketing, 19(3), 126-139. Retrieved from http:// www.emeraldinsight.com/doi/ abs/10.1108/02652320110388559

21. Oliver, R. L. (1999). Whence consumer loyalty? Journal of Marketing, 63(4), 33-44. Retrieved from https://www.jstor.org/stable/1252099

22. Parasuraman, A., Zeithaml, V. A., \& Berry, L. L. (1985). Problems and Strategies in Services Marketing. Journal of Marketing, 49, Spring, 33 46. Retrieved from https://www.jstor.org/stable/1251563?seq=1\#page_ scan_tab_contents

23. Parasuraman, A., Zeithaml, V. A., \& Berry, L. L. (1988). The SERVQUAL: A multiple-item scale for measuring consumer perceptions of service quality. Journal of Retailing, 64(1), $12-40$.

24. Robbins, S. P. (1990). Organizational theory: Structure, Design and Applications (5th. ed). Englewood Cliffs, N. J.: Prentice-Hall. Retrieved from http://www.goodreads.com/ book/show/11812488-organizationtheory

25. Rust, R. T., Zahorik, A. J., \& Keiningham, T. L. (1995). Return on Quality (ROQ): Making Service Quality Financially Accountable. Journal of Marketing, 59(2), 58-70. Retrieved from https://www.jstor. org/stable/1252073?seq=1\#page_ scan_tab_contents

26. Soteriou, A., S., Zenios A. (1999a). Operations, quality and profitability in the provision of banking services. Management Science, 45(9), 1221 1238.

27. Venkatraman, N., \& Ramanujam, V. (1986). Measurement of business performance in strategy research: A comparison of approaches. Management Science, 11(4), 801814. Retrieved from https://www. jstor.org/stable/258398

28. Zahorik, A. J., Rust, R. T. (1992). Swantrz T. A., Bower D. E., Brawn S. W., (Eds). Modelling the impact of Service Quality on Profitability: A Review. Retrieved from http:// ro.uow.edu.au/cgi/viewcontent.cgi?a rticle $=1003 \&$ context $=$ buspapers 